\title{
The study of cold storage and temperature controlled transportation: A case study of a chain restaurant in Thailand
}

\section{Soğuk hava deposu ve sıcaklık kontrollü taşımacılık çalışması: Tayland'da bir zincir lokantası örneği}

\author{
Pannita CHAITANGJIT ${ }^{\text {iD }}$, Pornthipa ONGKUNARUK2*ip \\ 1,2Department of Agro-industrial Technology, Faculty of Agro-industry, Kasetsart University, Bangkok, Thailand. \\ duan-pannita@hotmail.com,numorr@gmail.com
}

Received/Geliş Tarihi: 05.07.2019, Accepted/Kabul Tarihi: 19.10.2019

doi: $10.5505 /$ pajes.2019.81231

* Corresponding author/Yazışılan Yazar

Special Issue Article / Özel Sayı Makalesi

\begin{abstract}
The safety and quality of agricultural raw materials are important in the food service industry because raw materials are temperature sensitive and perishable. Hence, they should be stored in cold storage and temperature-controlled truck to maintain quality and safety. This study investigates the current cold chain management of a chain restaurant. The objective is to identify the problems and suggest how to establish the proper cold storages and temperature-controlled trucks. The scope of the study is a restaurant having nine branches, two refrigerated containers (20 feet) for storing raw material and three temperature-controlled trucks for sending raw material to each branch. We conduct in-depth interviews with the restaurant owner and operators and check the temperature in cold storage and during transportation of raw material by using an infrared thermal camera and data logger to identify the problem. Then, we analyze the causes of the problem and suggest solutions for the improvement such as the design of cold storage and delivery platform. In summary, this research will be beneficial to other cold storage and temperature-controlled truck users. It can enhance the cold chain efficiency and food safety as well as energy cost-saving.
\end{abstract}

Keywords: Cold chain management, Cold storage, Temperaturecontrolled truck, Restaurant, Energy saving

\section{Öz}

Tarımsal hammaddelerin güvenliği ve kalitesi gıda hizmet endüstrisinde önemlidir, çünkü hammaddeler sıcaklığa karşı hassastır ve bozulabilir. Bu nedenle, kalite ve güvenliği sağlamak için soğuk hava depolarında ve sıcaklık kontrollü araçlarda depolanmaları gerekir. $\mathrm{Bu}$ calıșma bir zincir restoranın mevcut soğuk zincir yönetimini incelemektedir. Amaç, sorunları belirlemek ve uygun soğuk hava depolarının ve sıcaklık kontrollü araçların nasıl kurulacağını önermektir. Calıșmanın kapsamı, dokuz șubesi, her bir şubeye hammadde göndermek için hammadde depolamak için iki frigorifik konteyner (20 feet) ve sicaklık kontrollü üç kamyondan olușan bir restorandır. Sorunu belirlemek için, restoran sahibi ve işletmecileri ile derinlemesine görüșmeler yapılmıș ve kızılötesi bir termal kamera ve veri kaydedici kullanarak soğuk hava deposu ve hammaddenin taşınması sırasındaki sıcaklığı kontrol edilmiștir. Ardından, sorunun nedenleri analiz edilmiş ve soğuk hava deposu ve dağıtım platformu tasarımı gibi iyileștirmeler önerilmiștir. Özetle, bu araștırma diğer soğuk hava depoları ve sıcaklık kontrollü kamyon kullanıcıları için faydalı olacaktır. Soğuk zincir verimliliğini, gıda güvenliğini ve aynı zamanda enerji maliyetinde tasarruf oranını artırabilir.

Anahtar kelimeler: Soğuk zincir yönetimi, Soğuk hava depoları, Sıcaklık kontrollü kamyon, Restoran, Enerji tasarrufu

\section{Introduction}

Recently, food service becomes an important industry in Thailand. In 2018, the expected market value of restaurant business in Thailand is about 411-415 billion baht with an increasing trend of about $4-5 \%$ from the previous year. In addition, the number of chain restaurants is also increasing due to the impact of expanding of supermarket branch and the improvement of service level and competitiveness of the restaurant business [1]. In the food service industry, the safety and quality of agricultural raw materials are important because raw materials are temperature sensitive and perishable. Hence, they should use cold chain management to maintain the quality, safety and prolong the shelf life of raw materials [2]. The cold chain management is to properly control temperature, moisture, environmental conditions and time throughout processes especially in storage, handling and transportation from an upstream to downstream supply chain [3],[4]. The Postharvest Education Foundation [4] suggested four steps to implement cold chain management for perishable foods during the postharvest including harvest, collection, packing, processing, storage, transport, and marketing until it reaches the end customer. These steps include 1) pre-cooling system, 2) cold storage, 3) chilling and freezing process and 4) temperature-controlled transportation. Cold chain logistics is the planning and management of the interactions and transitions among stakeholders, in order to keep foods at their optimum temperature for maintaining quality, food safety, and prevention of waste and economic losses. In addition, Kuo and Chen [5] developed an advanced Multi-Temperature Joint Distribution System for a food cold chain and used the multitemperature truck to deliver the products required different temperature in the same truck. Similarly, Hernandez [6] stated that in food service distribution there were two parts for monitoring. First, in a distribution center, the temperature in a storage area should have a wide range and can be separated for storing the products at the right temperature and delivery at the right time. Second, in the temperature control truck for delivery products required a different temperature, it should separate space to store products in different temperature ranges. In addition, there are good practices to prevent the product from being damaged such as proper handling method, handling equipment, transportation, and storage condition, packaging, product position, and ventilation [7]-[11]. The optimal food cold chain management tries to ensure that all 
types of perishable products with different temperature constraints will be kept at the greatest quality condition from the upstream to downstream in a supply chain including storage and distribution. The freshness and safety of food are guaranteed at every stage of logistics service such that the value and quality meet customers specification [2],[8],[12]. A causal loop diagram is a model used to analyze and identify causes and effect in their systems. It can be used as a tool for enhancing decision making. An application to identify the causes of the pollution problem in the dairy industry can be found in [13]. The causal loop diagram identified the mechanism of the internal dairy processes and the impact of inefficient use of resources. In addition, it was used to identify the causes of fresh vegetable loss in three major factors i.e. the original quality of vegetables, temperature and compression and impact in the cold chain logistics [14].

This research investigated the existing cold chain management of a case study chain restaurant located in Ayutthaya province in central Thailand. The restaurant produces barbecue meat and vegetables and other raw materials in a Japanese style and distributes them to nine shops in Bangkok, Ayuttaya, Saraburi, and Lopburi. A central kitchen with two external refrigerated containers (20 feet) at $-20{ }^{\circ} \mathrm{C}$ and an internal cold room for storing raw material. There are three temperature-controlled trucks at $-10{ }^{\circ} \mathrm{C}$ for sending raw material to restaurants. The objective was to identify the problems and suggest how to establish the proper cold storages and temperature-controlled trucks.

\section{Methodology}

First, we conducted in-depth interviews with a chain restaurant owner and operators for analyzing the current situation. The restaurant was chosen due to several reasons such as the willingness to share the data and allowing us to perform the experiment and the size of the restaurant could be a good representative for other SMEs. Next, we drew a swimlane diagram to explain the process of the restaurant. Then, we monitored the temperature in two refrigerated containers and three temperature-controlled trucks by using an infrared thermal camera and data logger to identify the problem. In refrigerated containers, three data loggers were placed in three locations i.e. the inner, central and near the door and an infrared thermal camera is used to check the temperature at a wall and raw materials. In a temperature-controlled truck, two data loggers were placed under the refrigerator and near a door as shown in Figure 1. After temperature analysis, we used the causal loop diagram for analyzing the causes of the problems. Finally, we suggest solutions to an owner for the improvement.

\section{Result and discussion}

\subsection{Business process analysis}

A swim lane diagram was drawn to represent the structures, time intervals among activities and their relationships with other functions in a central kitchen and restaurants. The activities were displayed in a square box with a number, and the length of the box implies the time interval between activities. The activity as a box was located in a row indicated the response functions of a stakeholder. The arrow identifies the direction of the relationship from one function or party to another function or party [15]. The process is as follows and shown in Figure 2.

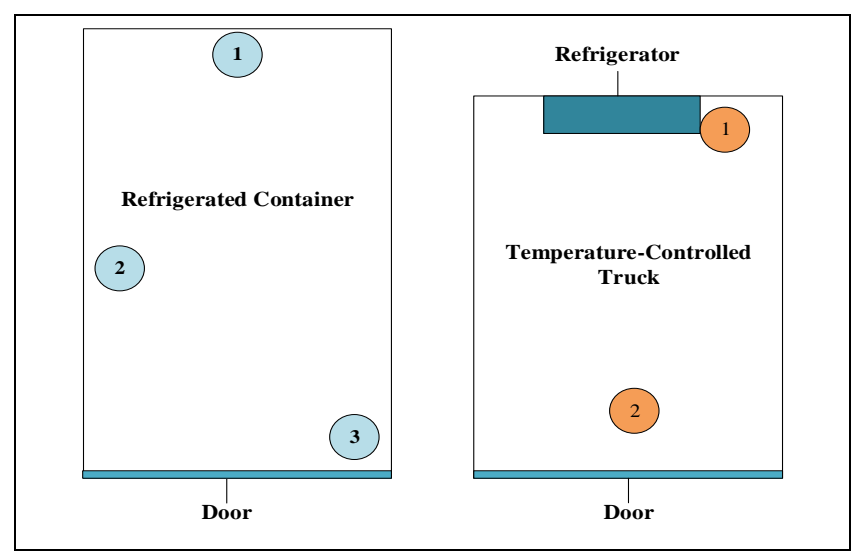

(a): Refrigerated container.

(b): Temperature-Controlled truck.

Figure 1: The location of data logger in refrigerated container and temperature-controlled truck (the number shows the location).

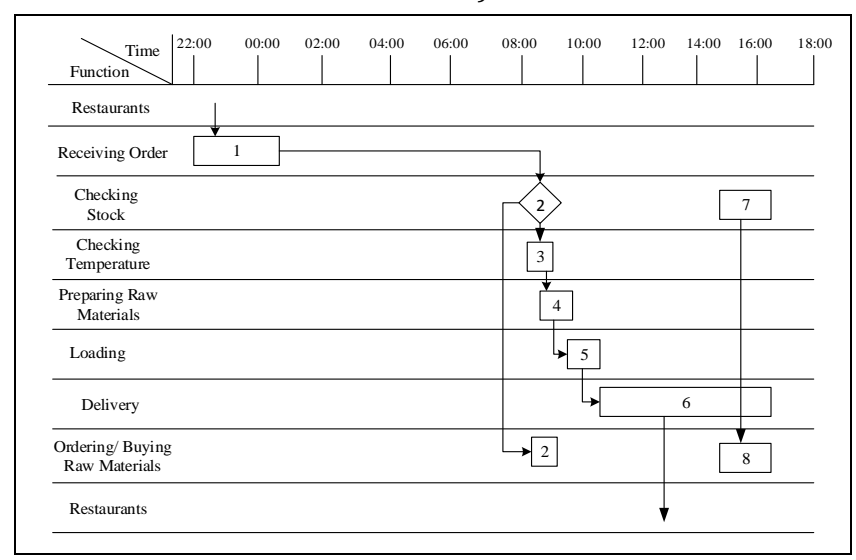

Figure 2: The swim lane diagram of a central kitchen.

First, the staff of a restaurant placed an order of raw materials to the purchasing department of a central kitchen at night (1). In the morning, the staff of a central kitchen will check the stocks of raw materials. If the stock is not enough, they will buy the raw materials at the nearest market (2). Then, the staff will record the temperature of a refrigerated container which must be less than $-18^{\circ} \mathrm{C}$ in a log book (3). After that, they will prepare the raw materials (4). Next, the raw materials are loaded in a temperature-controlled truck (5). For activity 4 and 5, they spend time for about 1 hour. Then, deliver raw material to the restaurant (6). After delivery, they will check stock again (7) and plan to order raw material from suppliers (8).

\subsection{Cold storage monitoring}

We check the temperature in the refrigerated container by the data logger and the result of the temperature shown in Table 1. The lowest temperature at the inner area of the refrigerated container is $-20.3{ }^{\circ} \mathrm{C}$ and lower than another area. For the average temperature, we found that the temperature at the inside of the refrigerated container is lower than other areas too. So if we consider about average temperature in the refrigerated container that they should store the raw material at the inner area and the central area in the refrigerated container because the temperature in that area is suitable for storing raw materials. 
At night, the temperature in a container fluctuates between $-10{ }^{\circ} \mathrm{C}$ to $-20^{\circ} \mathrm{C}$, then the thermostat works at 4 a.m. and the temperature is raised to $0{ }^{\circ} \mathrm{C}$ within $80 \mathrm{~min}$. or at about $0.25^{\circ} \mathrm{C}$ per minute. Then, a freezer is working again and temperature will drop to $-20^{\circ} \mathrm{C}$ within 2.5 hours or around $0.2^{\circ} \mathrm{C}$ per minute as shown in Figure 3. During the preparation of raw materials, the staff open the door around 15-30 minutes while the external temperature is about $30{ }^{\circ} \mathrm{C}-40{ }^{\circ} \mathrm{C}$. Hence, the temperature at the door area without anteroom is around $10^{\circ} \mathrm{C}$ $-15^{\circ} \mathrm{C}$ or the temperature is increased around $2{ }^{\circ} \mathrm{C}$ to $4{ }^{\circ} \mathrm{C}$ per minute. For the inner area and central area, the temperature is increased to around $1{ }^{\circ} \mathrm{C}$ to $3{ }^{\circ} \mathrm{C}$ per minute. When they closed the door, the temperature is dropped to $-10^{\circ} \mathrm{C}$ with an hour.
The temperature is decreased by around $0.5^{\circ} \mathrm{C}-1{ }^{\circ} \mathrm{C}$ per minute after closing the door. It implied that it takes a longer time to decrease the temperature to the target level, this results in higher electricity cost. In addition, the most vulnerable location is the door area while the inner area is the coldest.

Considering the temperature of the wall in the refrigerated container by the infrared thermal camera as in Figure 4 , the temperature of the wall is between $-0.2^{\circ} \mathrm{C}$ and $9.9^{\circ} \mathrm{C}$ which is higher due to improper insulation. However, the temperature of raw material in the refrigerated container is between $-8{ }^{\circ} \mathrm{C}$ to $-15^{\circ} \mathrm{C}$ which is considered as a safe condition.

Table 1: Average temperature in refrigerated container at central kitchen.

\begin{tabular}{lccc}
\hline \multirow{2}{*}{ The Position of Data Logger } & \multicolumn{2}{c}{ Average Temperature in Refrigerated Container $\left({ }^{\circ} \mathrm{C}\right)$} \\
\cline { 2 - 4 } & Minimum & Average & \multicolumn{2}{c}{ Maximum } \\
\hline Inner area & $20.3-$ & -14.0 & 4.0 \\
Central area & $16.5-$ & -11.9 & -0.4 \\
Front door & $15.6-$ & -7.5 & 17.1 \\
\hline
\end{tabular}

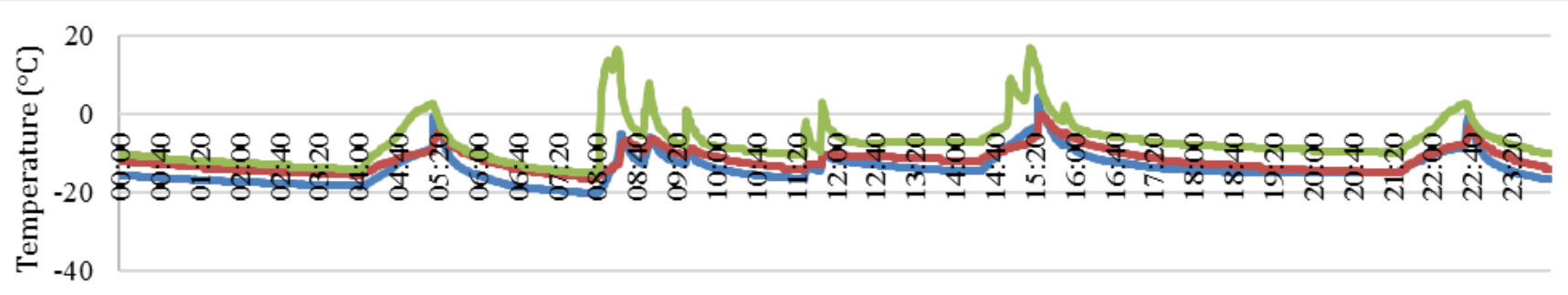

Inner Central $\longrightarrow$ Front door

Figure 3: The temperature in a refrigerated container at a central kitchen.
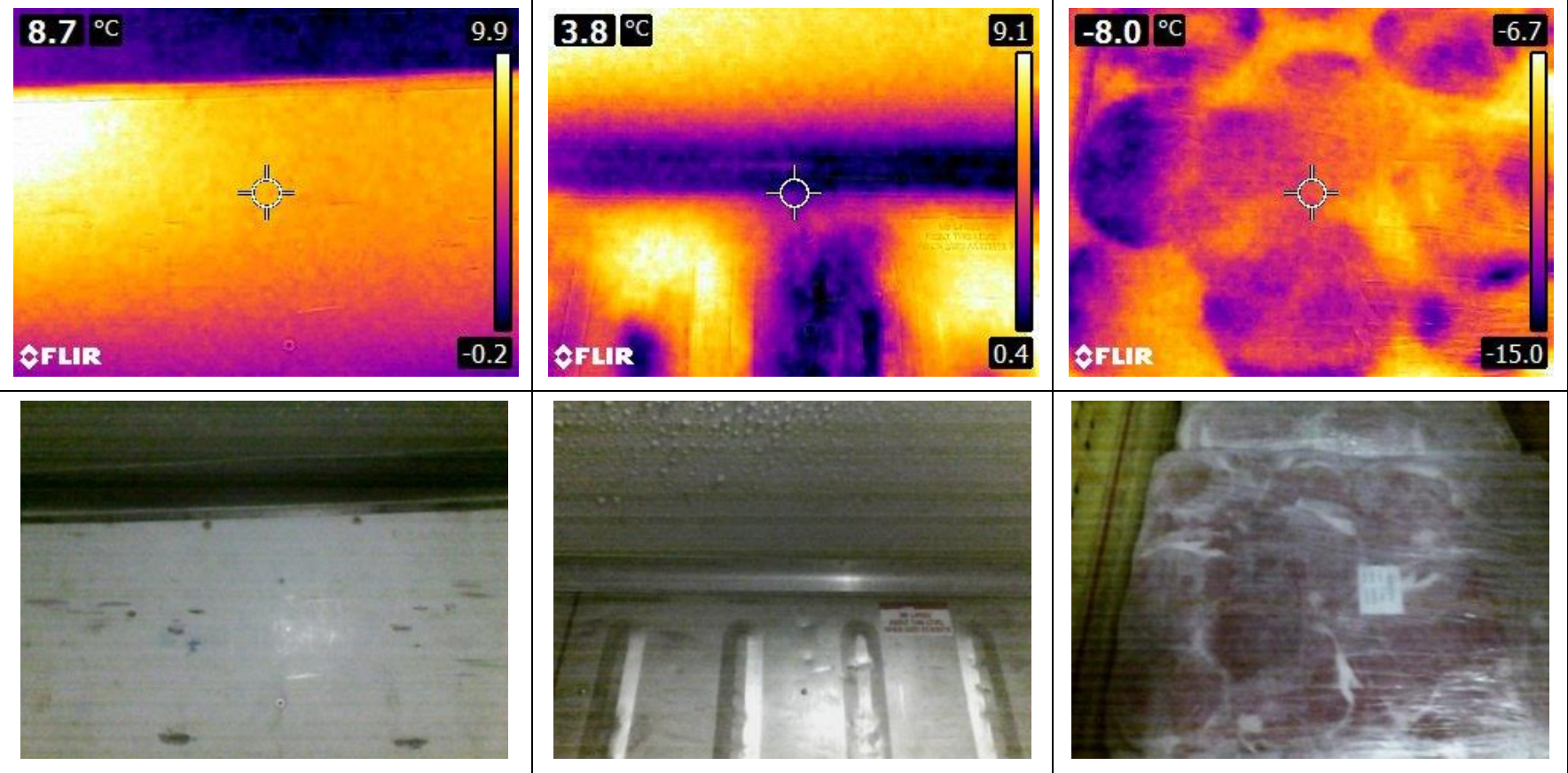

(a): The inner wall.

(b): Inside wall.

(c): Products.

Figure 4: The temperature in refrigerated container by infrared thermal camera. 


\subsection{Temperature-controlled truck monitoring}

In a temperature-controlled truck, the temperature at the door area is between $-7.53{ }^{\circ} \mathrm{C}$ to $23.40{ }^{\circ} \mathrm{C}$ as shown in Table 2 and Figure 5 which is mostly lower than the temperature at the under refrigerator area because of the cold air blows to that area. However, when the staff opens the door to unload, the temperature at the door area is increased and becomes higher than the other area about $2{ }^{\circ} \mathrm{C}$. During unloading, the temperature has fluctuated and the raw materials may be damaged. In general, the temperature at the door area is $5.83^{\circ} \mathrm{C}$ which is lower than in other areas around $3^{\circ} \mathrm{C}$. This implied that the air flow is not circulated so the difference of temperature in a temperature-controlled truck is high. Further investigate the other area should be done. In addition, air circulation should be established. We also found that the staff did not precool a truck before loading. It took 20-30 min. to decrease the temperature from $15{ }^{\circ} \mathrm{C}$ to $0{ }^{\circ} \mathrm{C}$ or around $0.5^{\circ} \mathrm{C}$ per minute.

\subsection{Identification of the causes of inefficient cold chain management}

After gathering the current practices and the above results, we investigated the causes of the inefficiency of the cold chain management by creating a causal loop diagram as in Figure 6. The plus sign means a positive effect whereas the minus sign implies the negative effect of the cause. There were four mains causes as follows. First, the lack of collaboration in a supply chain, if stakeholder in the supply chain has the right attitude to improve the efficiency of the cold chain management and have the common goal among stakeholders and have the agreement from the top management team, then the collaboration will be increased. On the other hand, the number of stakeholders affects the collaboration in the cold chain, the more the difficult. Second, the improper design of cold chain facilities and equipment. There were several causes of improper design of cold chain facilities and equipment such as the quality and quantity of current service providers, capital investment of the users and the knowledge. Third, best practices in a cold chain can improve the efficiency of cold chain management. Starting from the government's policy that should provide education on cold chain management in universities or institutes. Establish standards and provide handbook/guidelines including training for all stakeholders on cold chain management. In addition, measurement equipment such as data loggers and infrared cameras to check the temperature all stages in the cold chain, with a quality control system and audit system to ensure that the temperature is proper throughout the entire chain. Finally, without implementing the information technology infrastructure which is a foundation of the traceability system, cold chain management cannot be efficient due to big data of temperature and time. The restaurant can enhance the customer service level and save energy by considering to apply the above suggestions.

\subsection{The suggestion of cold chain management in} Thailand

Using the refrigerated container for storing raw material is not effective because there is no insulation and the ambient temperature affects the internal temperature of goods in the refrigerated container [3],[8],[10],[11]. In the loading area, establishing an anteroom can reduce the workload of a refrigerator.

Table 2: Average temperature in temperature-controlled truck.

\begin{tabular}{cccc}
\hline \multirow{2}{*}{ The Position of Data Logger } & \multicolumn{2}{c}{ Average Temperature in Temperature-Controlled Truck $\left({ }^{\circ} \mathrm{C}\right)$} \\
\cline { 2 - 4 } & Minimum & Average & Maximum \\
\hline Under the refrigerator & $2.94-$ & 8.18 & 21.82 \\
Near door & $7.53-$ & 5.83 & 23.40 \\
\hline
\end{tabular}

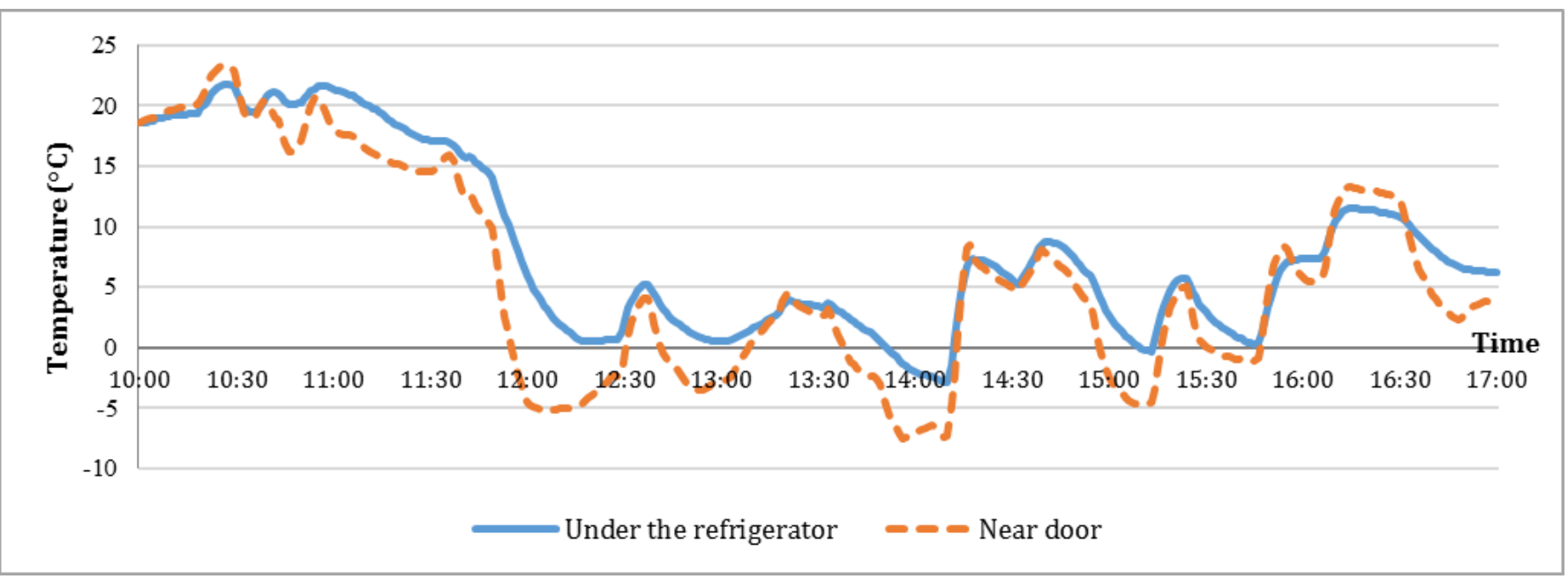

Figure 5: Average temperature in a temperature-controlled truck. 


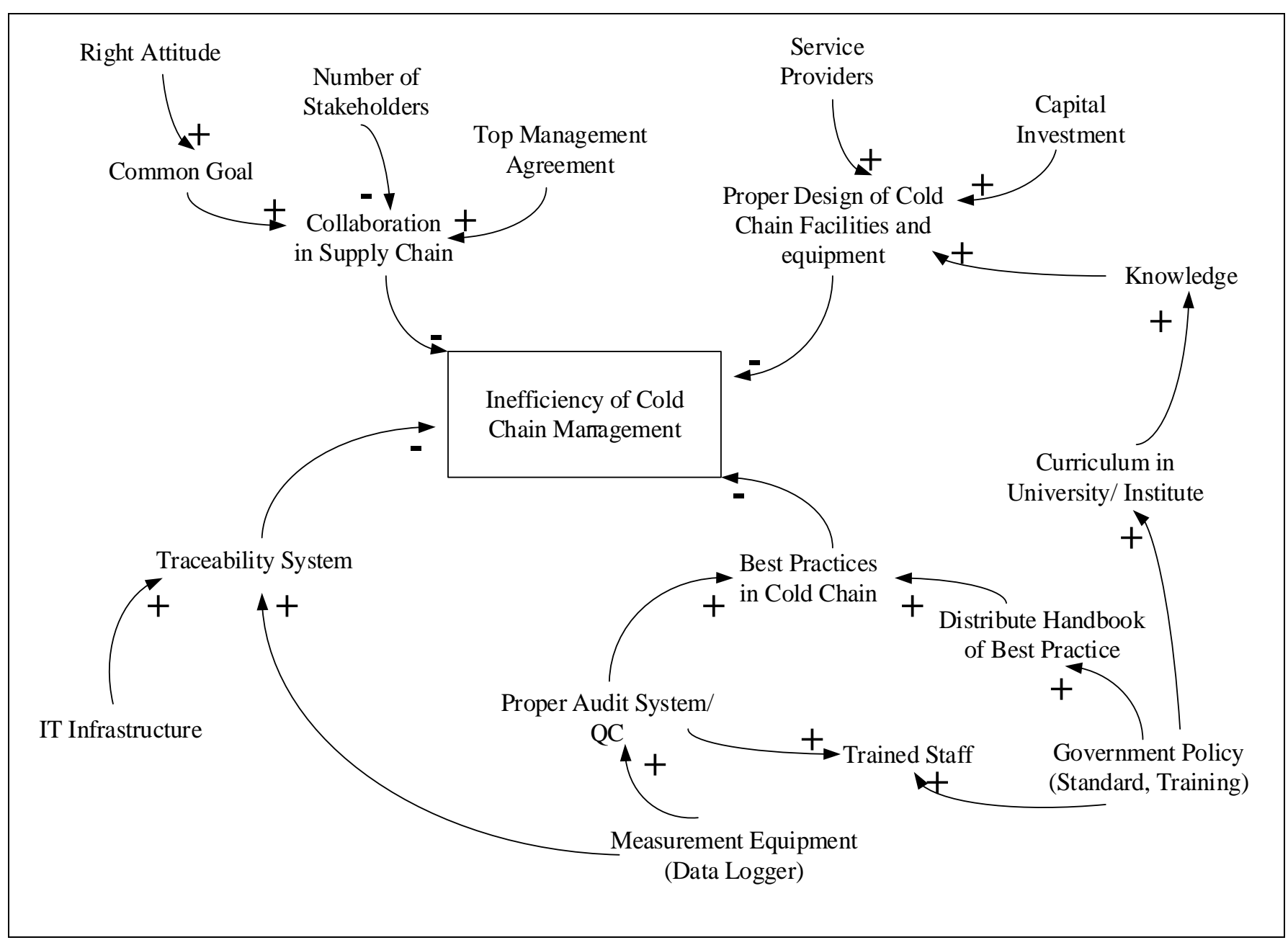

Figure 6: The causal loop diagram of inefficiency of cold chain management.

In addition, the proper layout in cold storage should be well developed. The staff should identify the right amount of raw materials to reduce the picking time and try not to open the door too long to save the energy [3],[10],[16],[17]. For a temperature-controlled truck, the precooling must be applied for 30 minutes to set up the temperature equal to the storage temperature. The proper design of air circulation should be established. In addition, the door should not open more than 15 minutes. If there are several types of raw materials required keeping in different temperature, it is suggested to separate the area in the storage room and truck. Raw materials should be placed and delivered in the appropriate temperature in the entire chain [8],[9],[18]. In Thailand, there is no standard manual for the proper range of temperature for each type of raw materials. Furthermore, there are various types of raw materials such as herb, fruits, and vegetables that are required different environment. In addition, more temperature control can be done by validating the temperature and control the procedure used by the central kitchen, especially for small and medium-sized enterprises [19],[20]. Further study can be extended to shelf life prediction or standardize the suitable environment for Thai food [21].

\section{Conclusion}

In this study, we explore the current practices in cold chain management of a small-sized chain restaurant using data loggers and a thermal infrared camera. The current practices are using improper insulating materials of a refrigerated container, no anteroom, long loading time, no precooling and poor air circulation in a temperature-controlled truck. This results in high energy consumption and increases the risk of the low quality of raw materials delivered to the restaurants. In addition, the restaurant did not have the data loggers to monitor the temperature in the cold storage and truck. These problems might be found in other chain restaurants in Thailand. Hence, we identified the causes and proposed how to solve the problems in the macro view. In short, the other cold storage and temperature-controlled truck users can regularly evaluate their practices so as to enhance the cold chain efficiency and food safety as well as energy cost-saving. Further study can be an analysis of proper temperature for each type of raw materials and also the shelf life of raw materials for different storage environment and time. 


\section{References}

[1] Kasikorn Research Center. "Forecast of Restaurant Market Volume in 2018 Expand by 4-5\%".

[2] https://www.kasikornresearch.com/th/analysis/kecon/business/Pages/36839.aspx (09.03.2018).

[3] Laguerre O, Hoang HM, Flick D. "Experimental investigation and modeling in the food cold chain: thermal and quality evolution". Trends in food science and Technology, 29(2), 87-97, 2013.

[4] Yuen SM, Simon. "Temperature controlled warehouse and cold chain business in hong Kong: a literature review". Asia Pacific Journal of Advanced Business and Social Studies, 3(1), 8-18, 2017.

[5] The Postharvest Education Foundation. "Use of Cold Chains for Reducing Food Losses in Developing Countries".

https://www.researchgate.net/publication/261759392 /download (09.03.2018).

[6] Kuo JC, Chen MC. "Developing an advanced multitemperature joint distribution system for the food cold Chain". Food control, 21, 559-566, 2010.

[7] Hernandez JA. "Foodservice Distribution : Maintaining the Cold Chain" https//:www.foodsafetymagazine.com/magazinearchive1/augustseptember-2009/foodservicedistribution-maintaining-the-cold-chain/ (05.03.2018).

[8] Laguerre 0, Hoang HM, Flick D. "Heat transfer modelling in a refrigerated display cabinet: the influence of operating conditions". Journal of Food Engineering, 108, 353-364, 2012.

[9] Taylor J. "Recommendations on the Control and Monitoring of Storage and Transportation Temperatures of Medicinal Products". The Pharmaceutical Journal, 267, 128-131, 2001.

[10] Bertheau DE, Osswalad V, Laguerre O, Alvarez G. "Cold Chain of Chilled Food in France". International Journal of Refrigeration, 52, 161-167, 2015.

[11] Gogou E, Katsaros G, Derens E, Alvarez G, Taoukis PS. "Cold Chain database development and application as a tool for the cold chain management and food quality evaluation". International Journal of Refrigeration, 52, 109-121, 2015.

[12] Vigneault C, Thompson J, Wu S, Hui KPC, Leblanc DI. "Transportation of fresh horticultural produce". Postharvest Technologies for Horticultural crops, 2, 1-24, 2009.

[13] Mercier S, Villeneuve S, Mondor S, Uysal I. "TimeTemperature Management Along The Food Cold Chain :A Review of Recent Developments". http/:onlinelibrary.wiley.com/doi/10.1111/1541 4337.12269/full (9.3.2018).
[14] Aikenhead G, Farahbakhsh K, Halbe J, Adamowski J. "Application of process mapping and causal loop diagramming to enhance engagement in pollution prevention in small to medium size enterprises: case study of a dairy processing facility". Journal of Cleaner Production, 102, 275-284, 2015.

[15] Rattanawong A, Ongkunaruk P. "Reduce loss during transportation: a case study of fresh vegetables in Thailand". $3^{\text {rd }}$ International Conference on Agro-Industry 2016-Competitive \& Sustainable Agro-Industry: Value Creation in Agribusiness". Bangkok, Thailand, 09-11 November 2016.

[16] Chueprasert M, Ongkunaruk P, Ongcunaruk W. "The study of business process and decision support of raw milk blending for a collecting centre in Thailand". International Food Research, 23(3), 1233-1238, 2016.

[17] Palmer A. "Challenges Best Practices of Cold Storage Warehouse Management". https://www.refrigeratedfrozenfood.com/articles/9192 3-challenges-best-practices-of-cold-storage-warehousemanagement (09.03.2018).

[18] Devenish D. "4 Best Practices for Cold Storage and Food Warehouse Management". https://badgeraustralia.com.au/4-best-practices-forcold-storage-and-food-warehouse-management (26.05.2018)

[19] Hsiao HY, Chen CM, Chin LC. "Distribution planning for perishable foods in cold chains with quality concerns: formulation and solution procedure". Trend in Food Science and Technology, 61, 80-93, 2017.

[20] Lundén J, Vanhanen V, Myllymäki T, Laamanen E, Kotilainen K, Hemminki K. "Temperature control efficacy of retail refrigeration equipment". Food Control, $45,109-114,2014$

[21] Zubeldia BB, Jiménez MN, Claros MTV, Andrés JLM, Martin-Olmedo P. "Effectiveness of the cold chain control procedure in the retail sector in Southern Spain". Food Control, 59, 614-618, 2016.

[22] Theofania T, Efimia D, Marianna G, Eleni G, George K, Petros T. "Shelf-life prediction models for ready-to-eat fresh cut salads: Testing in real cold chain". International Journal of Food Microbiology, 240, 131-140, 2017. 